\title{
Extending sapwood - Leaf area relationships from stems to roots in Coast Douglas-fir
}

\author{
Peter J. GoulD ${ }^{1 *}$, Constance A. HARRINGTON ${ }^{1}$ \\ USDA Forest Service, Pacific Northwest Research Station. 3625 93rd Ave SW, Olympia, WA 98512, USA
}

(Received 16 May 2008; accepted 30 August 2008)

\section{Keywords: sapwood / heartwood / roots / leaf area / Douglas-fir}

Mots-clés : aubier / bois de cœur / racines / surface foliaire / Douglas vert

\begin{abstract}
- Studies of allometric relationships between leaf area and the cross-sectional area (CSA) of sapwood in the stem have shed light on the structural and functional relationships between water-conducting and photosynthetic tissues.

- The purpose of this study was to test whether sapwood-leaf area relationships could be extended from stems to roots in coast Douglas-fir (Pseudotsuga menziesii var. menziesii (Mirb.) Franco). Twelve trees were felled, their stumps were excavated, and the CSA of sapwood and heartwood were estimated for individual roots, entire root systems, and stem section.

- Root sapwood CSA was greater than sapwood CSA throughout the stem, and the ratio of leaf area to sapwood CSA $\left(\mathrm{A}_{l}: \mathrm{A}_{s}\right)$ was accordingly lower for root sapwood. The relationship between sapwood CSA and leaf area was more variable in roots and at groundline compared to crown base. Root $\mathrm{A}_{l}: \mathrm{A}_{s}$ decreased with relative tree height (tree height/mean stand height).

- The strong allometric relationship between leaf area and the CSA of sapwood in the stem generally holds when extended to roots. The greater CSA of sapwood in roots versus stems may reflect differences in their roles in supporting the tree.
\end{abstract}

Résumé - Extension des relations aubier-surface foliaire des troncs aux racines chez le Douglas vert.

- Les études des relations allométriques entre la surface foliaire et la surface de la section (CSA) d'aubier dans le tronc ont éclairci les relations structurelles et fonctionnelles entre tissus conduisant l'eau et tissus photosynthétiques.

- Le but de cette étude était d'évaluer si les relations aubier-surface foliaire pouvaient être étendues des tiges aux racines chez le Douglas vert (Pseudotsuga menziesii var. menziesii (Mirb.) Franco). Douze arbres ont été abattus, leurs souches ont été déterrées et le CSA de l'aubier et du bois de cœur ont été évalués chez des racines individuelles, des systèmes racinaires entiers et dans la section du tronc.

- L'aubier des racines CSA était plus important que le CSA de l'aubier partout dans le tronc et le rapport de la surface foliaire au CSA de l'aubier (Al:As) était en conséquence plus bas pour l'aubier de racine. La relation entre le CSA de l'aubier et la surface foliaire était plus variable dans les racines et au collet comparativement à la base de la couronne. Le rapport $\mathrm{Al}$ :As a diminué avec la hauteur relative de l'arbre (hauteur de l'arbre/hauteur moyenne du peuplement).

- La relation allométrique forte qui existe entre la surface foliaire et le CSA de l'aubier dans le tronc se maintient généralement quand elle est étendue aux racines. Le plus grand CSA de l'aubier dans les racines comparativement aux troncs peut refléter des différences dans leurs rôles dans le support de l'arbre.

\section{INTRODUCTION}

The study of allometric relationships has been an important approach for elucidating functional relationships

* Corresponding author: pgould@fs.fed.us between plant organs, especially relationships between waterconducting and photosynthetic tissues (Margolis et al., 1995; McDowell et al., 2002; Wright et al., 2006). Such studies are typically premised on the pipe-model theory (Shinozaki et al., 1964a, 1964b) which posits that photosynthetic tissues are supported by a proportional amount of conductive tissue. 
In trees, the pipe-model theory describes the relationship between foliage (usually measured as leaf area) and the crosssectional area (CSA) of conductive tissue (sapwood). Many studies have found evidence for a constant ratio between leaf area and sapwood area $\left(\mathrm{A}_{l}: \mathrm{A}_{s}\right)$ as predicted by the pipe-model theory (Margolis et al., 1995), but numerous exceptions argue against a simple interpretation of the theory. $\mathrm{A}_{l}: \mathrm{A}_{s}$ is modified by several factors for a given species, including the availability of water and nutrients (Brix and Mitchell, 1983; Margolis et al., 1995; Mencuccini and Grace, 1995). $\mathrm{A}_{l}: \mathrm{A}_{s}$ also decreases with tree height, possibly to compensate for lower hydraulic conductance per unit sapwood area (McDowell et al., 2002). The role of wood in providing mechanical support also influences the distribution of sapwood and can considerably alter the value of $\mathrm{A}_{l}: \mathrm{A}_{s}$ depending on where sapwood is measured. $\mathrm{A}_{l}: \mathrm{A}_{s}$ typically conforms best to the pipe-model theory when sapwood is measured at crown base (Waring et al., 1982). Sapwood area decreases with height within the stem (Maguire and Hann, 1987); therefore $\mathrm{A}_{l}: \mathrm{A}_{s}$ is typically lower for a given species when sapwood is measured from diameter at breast height (dbh) than when it is measured at crown base (Monserud and Marshall, 1999; Waring et al., 1982). Most applications of the pipe model theory have focused on above-ground stems, but the same concepts can be extended to roots. Several studies have reported relationships that suggest stem CSA is equal to, or proportional to, the summed CSA of roots. The sum of the cross-sectional area of roots has been shown to be approximately equal to stem cross-sectional area at groundline in small $(<13 \mathrm{~cm}$ diameter at groundline) loblolly pine (Pinus taeda L.) and shortleaf pine (Pinus echinata Mill.) (Carlson and Harrington, 1987). Kuiper and Coutts (1992) found a constant relationship in small $(<13 \mathrm{~cm}$ dbh) coast Douglas-fir (Pseudotsuga menziesii var. menziesii (Mirb.) Franco) when root CSA was compared to CSA at breast height; however, root CSA exceeded breast-height CSA for large trees (>13 cm dbh). Root CSA was also found to exceed CSA at breast height in Norway spruce (Picea abies L.) that were larger than $11 \mathrm{~cm}$ dbh (Drexhage and Gruber, 1999). The presence of heartwood in roots was not considered in these studies; however, it is an important consideration when evaluating functional relationships under the pipe-model theory (Richardson and zu Dohna, 2003).

Shinozaki et al. (1964a) recognized the presence of "disused pipes" in plants, alluding to the partition between functional sapwood and non-conductive heartwood. Heartwood formation is typically viewed as a means of reducing the respiration costs of older, less conductive sapwood while maintaining an optimal value of $\mathrm{A}_{l}: \mathrm{A}_{s}$. Sapwood is transformed to heartwood through a complex process marked by the production of protective compounds (extractives), the development of barriers between the heartwood and the transpiration stream, and the death of living cells (Hillis, 1987; Spicer, 2005). Recent work indicates that the formation of heartwood is an active process rather than simply the result of cell aging or lack of oxygen within the bole (Spicer, 2005; Spicer and Holbrook, 2007). The rate of heartwood formation is, to some degree, sensitive to changes in a tree's physiological status as demonstrated by experimental pruning studies (Langstrom and Hellqvist, 1991; Margolis et al., 1988). The distribution of heartwood may also correlate with changes in the distribution of sapwood due to external mechanical stimuli (thigmomorphogenesis) (Berthier et al., 2001). Thus, the quantity and distribution of heartwood within trees may provide insight, in addition to that provided by the study of sapwood alone, into the factors that influence the physiological and mechanical functions of wood.

The purpose of this study was to examine the quantity and distribution of sapwood and heartwood within coast Douglasfir roots and relate them to more widely studied relationships between stem sapwood and leaf area. Our specific objectives were to: (1) quantify the CSA of sapwood and heartwood in individual roots (and for the sum of the first-order lateral roots) and evaluate their relationship with root size and growth rate, (2) compare the CSA of sapwood in roots with that measured in the stem, and (3) compare leaf area - sapwood CSA relationships when sapwood is measured in roots and in the stem and evaluate some factors that may contribute to differences in these relationships.

\section{MATERIALS AND METHODS}

\subsection{Field sampling}

Twelve trees with crowns in the upper canopy were sampled in summer 2006 from six stands within Capitol Forest (location = $46.9^{\circ} \mathrm{N}, 123.1^{\circ} \mathrm{W}$, elevation $=130$ to $330 \mathrm{~m}$ above sea level) near Olympia, WA, USA. The stands were established between 1983 and 1986 by planting bare root seedlings. Soils were deep productive Olympic clay loam and Olympic silt loam weathered from igneous rock. (USDA NRCS 2006). Diameters of sampled trees at $1.3 \mathrm{~m}$ above ground ranged from 12.1 to $38.0 \mathrm{~cm}($ mean $=24.1 \mathrm{~cm})$; heights ranged from 11.7 to $23.6 \mathrm{~m}($ mean $=17.9 \mathrm{~m})$. Trees were felled and total height and height to the base of the live crown were measured. Stem cross sections were removed at four heights relative to groundline $(0,1.3 \mathrm{~m}, 2.3 \mathrm{~m}$, and $3.3 \mathrm{~m})$ and three heights relative to the base of the live crown (crown base, one-third of the crown length, and two-thirds of the crown length). Three branches in each crown third (nine branches/tree) were randomly selected for removal for leaf-area measurements. The stumps were excavated and roots were cut at approximately $20 \mathrm{~cm}$ from the stump mass. The stumps (i.e., the lower $30 \mathrm{~cm}$ of the bole and the below-ground root mass) were completely removed from the ground and transported to our laboratory where they were cleaned prior to measurement.

\subsection{Sapwood and heartwood measurement}

The diameters of all first-order lateral roots $>1 \mathrm{~mm}$ were measured approximately $15 \mathrm{~cm}$ from the stump mass to avoid the zone of rapid taper close to the stump. Root cross sections were removed at the same point where diameters were measured. A $0.1 \%$ solution of methyl orange in water (Kutscha and Sachs, 1962) was applied to the stem and root cross sections to improve the visibility of the sapwoodheartwood boundary. Methyl orange is a $\mathrm{pH}$ indicator that clearly distinguished heartwood (stained red to orange) from sapwood (stained yellow). Total diameter inside bark was measured on each section on 
two perpendicular axes. Heartwood diameter was measured on one axis on stem sections, which were circular, and on two axes on root sections, which tended to be elliptical. The numbers of growth rings in sapwood and heartwood were counted for each root and stem section. A growth ring was counted as sapwood only if it was entirely free of heartwood. Total CSA and CSA of heartwood were calculated assuming stem sections were circular $\left(\operatorname{area}=\pi \cdot \mathrm{d}^{2} / 4\right)$ and root sections were elliptical $\left(\right.$ area $\left.=\pi\left(\mathrm{d}_{1} \cdot \mathrm{d}_{2}\right) / 4\right)$. The CSA of sapwood was calculated as total area minus the area of heartwood. Heartwood area was estimated for some small roots where it was not directly measured; however, these estimates accounted for less than $5 \%$ of total root area in the sampled trees.

\subsection{Leaf area measurements}

Measurements on the sampled branches were used to develop an equation to estimate the leaf mass of individual branches from branch diameter and relative crown position. Leaf mass was multiplied by specific leaf area (SLA; area per unit mass) to estimate branch-level leaf area, and branch-level leaf areas were summed to estimate wholetree leaf areas. Two samples of 100 needles each were taken from one branch in each crown-third of each tree to determine the relationship between leaf area (fresh needles) and leaf mass (oven dried). Leaf area was measured on one sample using a LI-3000 area meter (LICOR Biosciences, Lincoln, Nebraska USA). The second sample was oven dried and weighed. All remaining needles were removed from each branch, oven dried, and weighed.

Branch diameter and relative crown position were statistically significant predictors of leaf mass $(p<0.001)$ and accounted for $79.3 \%$ of its observed variation. The leaf mass equation was:

leaf mass $(\mathrm{g})=\left(26.7475-6.2664 \cdot C_{1}+8.8872 \cdot C_{2}\right) \cdot D^{2.1345}$

where $C_{1}=1$ if lower third of the crown, 0 if middle third, -1 if upper third; $C_{2}=0$ if lower third of the crown, 1 if middle third, -1 if upper third; $D=$ branch diameter $(\mathrm{cm})$.

Analysis of variance indicated that mean SLA differed significantly between crown thirds $(d f=2,30 ; p=0.03)$. SLA was highest in the lower third of the crown $\left(92.4 \mathrm{~cm}^{2} / \mathrm{g}\right)$ and was approximately equal in the middle and upper thirds of the crown (79.6 and $78.6 \mathrm{~cm}^{2} / \mathrm{g}$, respectively). SLA values specific to each crown position were used to estimate branch-level leaf area from leaf mass.

\subsection{Statistical analyses}

The allometric equation $\left(y=a_{0} X^{a_{1}}\right)$ was used to quantify relationships between sapwood CSA and other quantities (e.g., leaf area). The scaling coefficient of the allometric equation $\left(\alpha_{1}\right)$ determines the rate of change in a proportional relationship; a coefficient of 1.0 indicates a constant proportion (i.e., linear relationship), while values lower or higher than 1.0 indicate decreasing or increasing proportional relationships, respectively (Niklas, 1994). Non-linear leastsquares (NLS) regression (Schabenberger and Pierce, 2002) was used to estimate the coefficients of the allometric equations. Allometric equations typically do not include a clear independent and dependent variable; however, leaf area and $\mathrm{A}_{l}: \mathrm{A}_{s}$ were used as dependent variables in allometric equations and other analyses since leaf area was estimated with less precision (using the branch-level leaf mass model and SLA) than other quantities. Measurement error in the dependent variable does not violate any assumptions of regression. Measurement error in the independent variable, however, can have a considerable effect on coefficient estimates (McArdle, 2003).

To quantify the proportion of sapwood and heartwood in individual roots, an allometric equation was fit relating sapwood CSA to total CSA. The equation was then applied to small roots where heartwood was not measured and the results were added to the tree-level estimates of root heartwood CSA. The consistency of the leaf area sapwood area relationship when sapwood was measured in different sections of the tree was evaluated by comparing allometric equations and by testing for differences in $\mathrm{A}_{l}$ : $\mathrm{A}_{s}$ using a linear mixed-effects model to account for repeat measurements on the same tree (Pinheiro and Bates, 2000). Total leaf area was used to calculate $\mathrm{A}_{l}: \mathrm{A}_{s}$ for stem sections at or below crown base. Leaf area in the upper one-third and two-thirds of the crown was used to calculate $\mathrm{A}_{l}: \mathrm{A}_{s}$ for the respective upper stem sections. Ordinary least-squares (OLS) regression models (Neter et al., 1996) were used to test whether root $\mathrm{A}_{l}: \mathrm{A}_{s}$ was correlated with three variables associated with tree leaning or toppling due to wind: tree height/mean stand height, tree diameter at $1.3 \mathrm{~m} /$ mean stand diameter, and tree height/tree diameter (H/D) (Harrington and DeBell, 1996). Mean stand height and mean stand diameter were estimated from large permanent plots located adjacent to the sampled trees. The R programming language was used for all statistical analyses (Pinheiro et al., 2006; R Development Core Team, 2006).

\section{RESULTS}

\subsection{Sapwood and heartwood in individual roots}

The proportion of total root CSA in sapwood decreased with increasing root size (Fig. 1a). The scaling coefficient of the equation relating sapwood area to total area $(0.8501)$ was significantly less than 1.0 (95\% confidence intervals $=0.8025$ to 0.8996$)$. Staining with methyl orange indicated that heartwood was present on $68 \%$ of the sampled roots. Small roots were less likely to contain heartwood than large roots; only $51 \%$ of roots $<50 \mathrm{~cm}^{2} \mathrm{CSA}$ contained heartwood. Additionally, some large roots had relatively little heartwood; one root with a CSA of $277 \mathrm{~cm}^{2}$ had less than $5 \mathrm{~cm}^{2}$ of heartwood. The area that stained as heartwood was frequently elliptical in root sections and did not always conform to the shape of the growth rings (i.e., only part of some rings indicated heartwood). Root heartwood tended to stain close to red (indicating $\mathrm{pH}<3.4$ ), while stem heartwood tended to stain between red and orange $(\mathrm{pH}>3.4$ to 4.4$)$. Heartwood was noticeably drier than sapwood in the sampled roots, indicating that it was isolated from the transpiration stream in the same manner as stem sapwood.

The number of sapwood rings was not significantly correlated with total root age (i.e., total number of growth rings in cross section); however, slow-growing roots $\left(<5 \mathrm{~cm}^{2} / \mathrm{y}\right)$ tended to maintain a higher number of sapwood rings compared to roots that grew more rapidly (Fig. 1b). Radial growth rates were calculated by dividing total area by the total number of rings (i.e., total root age). On average, root cross-sections had 8.9 rings of sapwood and 5.5 rings of heartwood. In comparison, stem cross-sections removed at $1.3 \mathrm{~m}$ had an average of 8.6 rings of sapwood and 10.2 rings of heartwood. Root sections that grew $<5 \mathrm{~cm}^{2} / \mathrm{y}$ had an average of 9.4 rings of sapwood; those that grew $>10 \mathrm{~cm}^{2} / \mathrm{y}$ had an average of 6.8 rings 

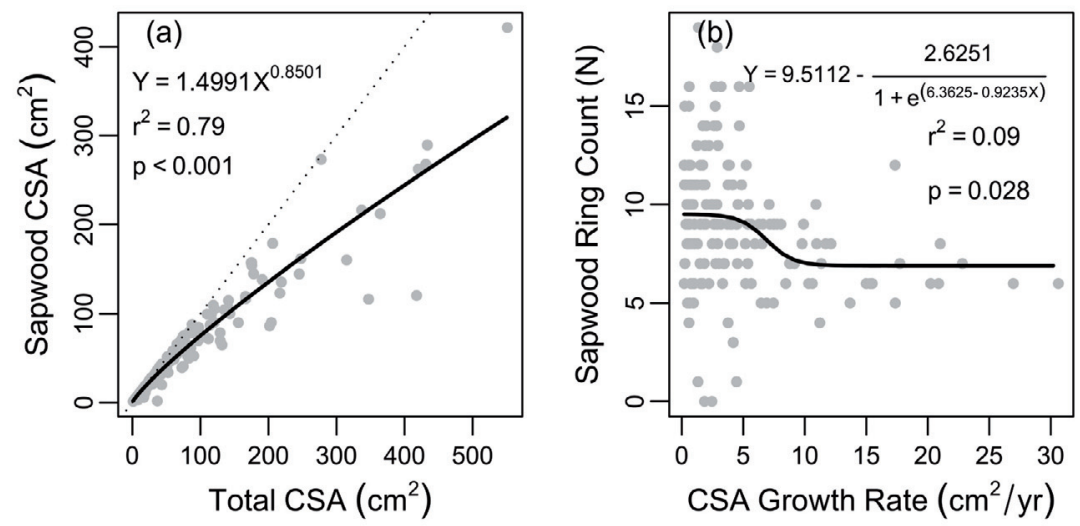

Figure 1. Summary of sapwood in individual root cross sections $(n=193)$. The cross-sectional area (CSA) of sapwood is shown in relation to the total CSA of the root (a). The vertical distance between the 1:1 line (dotted line) and each point is equal to the heartwood CSA of the root. The number of growth rings in sapwood is shown in relation to the CSA growth rate over the life of the root (b). The results of nonlinear least-squares regression fits are shown.

of sapwood. The variability in the number of sapwood rings per root section was also much greater in slow-growing roots than in roots that grew more rapidly.

\subsection{Sapwood and heartwood throughout the trees}

The distribution of sapwood and heartwood within trees and their relationship to leaf area were illustrated by generating a scaled representation of each tree (Fig. 2). Total stem CSA in all trees followed a typical parabolic shape of increasing area from the tip to groundline. The increase in CSA with decreasing height generally extended below ground; total root CSA was $18 \%$ greater, on average, than total CSA at groundline. Three trees (1-B, 4-A, and 6-B) had slightly less total root CSA than CSA at groundline. The rate of taper in heartwood CSA above ground mirrored that of overall stem taper. In most trees, heartwood CSA decreased markedly from groundline to roots $\left(\mathrm{A}_{\text {root }}=0.747 \cdot \mathrm{A}_{\text {groundline }}\right)$, despite the typical increase in total root CSA. The sole exception was tree 5-A where heartwood CSA increased by $7 \%$ between groundline and roots. Tree 5-A also had the greatest increase in total CSA between groundline and roots (53\%). On average, $19 \%$ of root CSA was comprised of heartwood. In contrast, heartwood comprised 38 and $33 \%$ of stem CSA at $1.3 \mathrm{~m}$ and groundline, respectively. The relationship between total root CSA and sapwood CSA was nonlinear with the proportion of sapwood decreasing with total root area $\left(\mathrm{A}_{\text {sap }}=5.9162 \cdot \mathrm{A}_{\text {total }}^{0.7772}, p<0.001, r^{2}=0.94\right)$. Tree 5-A had the greatest percentage of total root CSA in heartwood $(48 \%)$.

\subsection{Allometric relationships with leaf area}

The relationship between sapwood CSA at crown base and leaf area was highly predictive $\left(r^{2}=0.98\right)$, but greater variation was evident when sapwood CSA was measured at groundline $\left(r^{2}=0.87\right)$ or in roots $\left(r^{2}=0.81\right)$ (Fig. 3). Tree 5-A (filled point in Fig. 3) was not used to estimate equation coefficients due to its high leaf area relative to sapwood CSA at crown base. The high leaf area may be due to error in the estimation of crown area; however, the individual branches from tree 5-A were not outliers in the leaf mass equation that was used to estimate leaf area. The scaling coefficient of the allometric equation was significantly greater than 1.0 by a small margin $(95 \%$ confidence interval $=1.0450$ to 1.4608$)$ when sapwood was measured at crown base; it did not differ significantly from 1.0 when sapwood was measured at groundline or within roots.

$\mathrm{A}_{l}: \mathrm{A}_{s}$ was significantly lower when sapwood CSA was measured within roots $(0.22)$ than when it was measured at any location within the stem other than at groundline (Fig. 4). Groundline $\mathrm{A}_{l}: \mathrm{A}_{s}$ (0.34) was also significantly lower than $\mathrm{A}_{l}: \mathrm{A}_{s}$ higher on the stem. $\mathrm{A}_{l}: \mathrm{A}_{s}$ was fairly constant throughout the rest of the stem and values (0.53 to 0.79$)$ were generally consistent with published results for coast Douglas-fir (Brix and Mitchell, 1983; Margolis et al., 1995; McDowell et al., 2002; Waring et al., 1982); however, $\mathrm{A}_{l}: \mathrm{A}_{s}$ was significantly lower at $1.3 \mathrm{~m}$ and at two-thirds of the crown length than it was at one-third of the crown length.

$\mathrm{A}_{l}: \mathrm{A}_{s}$ was significantly correlated with relative height ( $p=$ 0.037 ), but not with relative diameter or H/D (Fig. 5). The negative relationship between $\mathrm{A}_{l}: \mathrm{A}_{s}$ and relative height indicated that trees taller than the stand average had more root sapwood CSA per unit leaf area than shorter trees. Tree 5-A, which had high $\mathrm{A}_{l}: \mathrm{A}_{s}$ and was an outlier in the allometric relationships between leaf area and sapwood CSA, had a low relative height and conformed closely to the overall trend. Despite the relationship with relative height, the relationship between $\operatorname{root} \mathrm{A}_{l}: \mathrm{A}_{s}$ and total tree height was not statistically significant $(p=0.69)$. Stem $\mathrm{A}_{l}: \mathrm{A}_{s}$ was found to decrease in Douglasfir as tree height increased when a much greater range of tree heights was examined than in the present study (McDowell et al., 2002). 

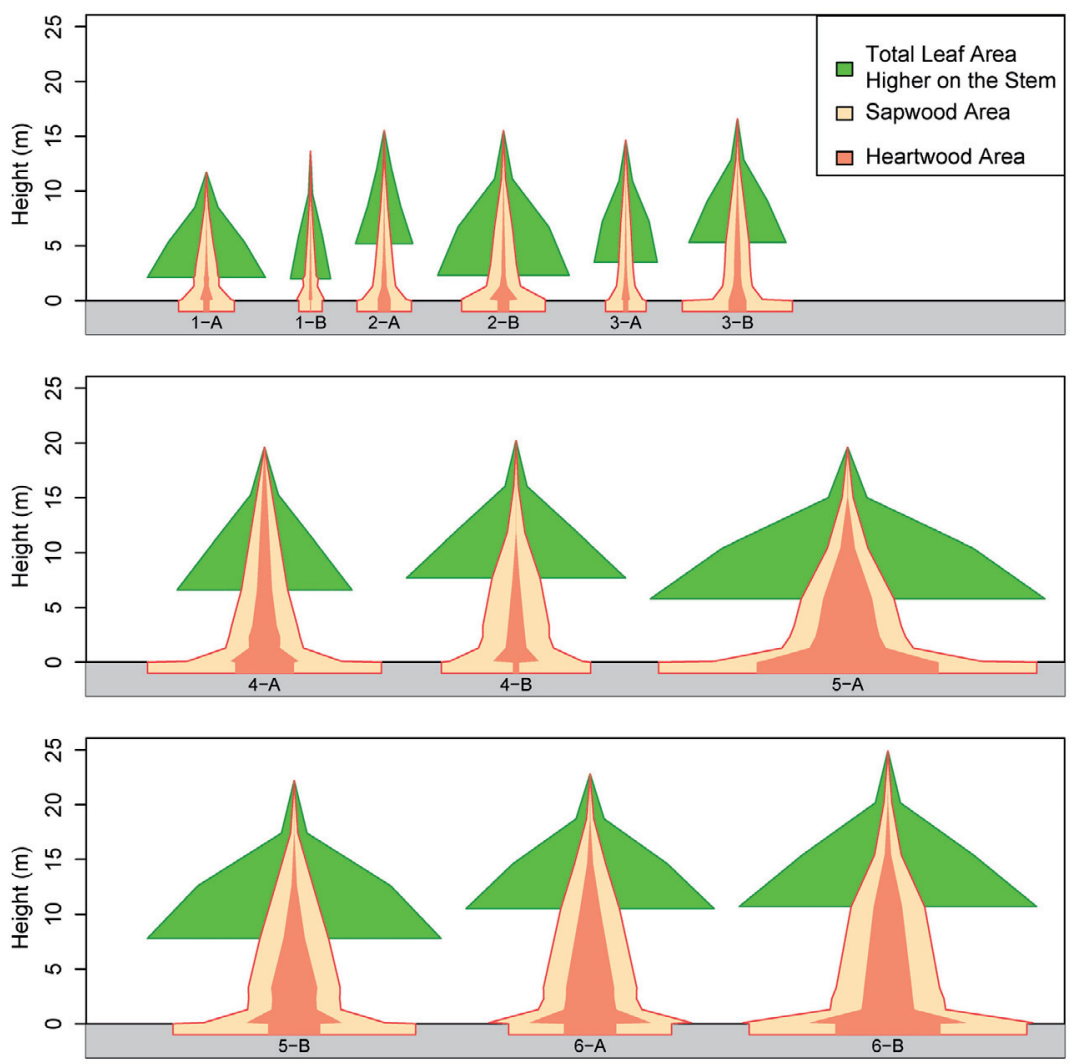

Figure 2. Scaled representation of leaf area, sapwood cross-sectional area (CSA), and heartwood CSA for Douglas-fir sampled in six stands at Capitol Forest, WA. Units on the x-axes are arbitrary but sapwood and heartwood CSA are shown in the same units for all trees. Leaf area is shown using a smaller unit than the CSA of sapwood and heartwood but it is also consistent for all trees. Leaf area is shown as the total leaf area in the crown above each one-third of the crown length; therefore, the width of the crown base shows total leaf area. The area below ground (height $<0 \mathrm{~m}$ ) represents the CSA of sapwood and heartwood in roots. Labels shown below each tree refer to the stand number and tree identifier.

Allometric equations were fit to relate total root CSA to CSA at groundline and at $1.3 \mathrm{~m}$ above groundline (Fig. 6a), and root sapwood CSA to sapwood CSA at groundline and at $1.3 \mathrm{~m}$ (Fig. 6b). The four equations were statistically superior to their respective null hypotheses of an invariant mean $(p<0.001)$ and had similar coefficients of determination $\left(r^{2}=0.80\right.$ to 0.89$)$. The scaling coefficients were all close to 1.0 and included 1.0 in their respective $95 \%$ confidence intervals. On average, total root CSA was only somewhat greater than total CSA at groundline, especially for small trees. However, root sapwood CSA was consistently greater than sapwood CSA at groundline or at $1.3 \mathrm{~m}$. The allometric relationships between diameter outside bark (DOB) at $1.3 \mathrm{~m}$ and total root CSA and root sapwood CSA may be useful for predicting root characteristics from inventory data. The coefficient estimates for these equations were:

$$
\begin{aligned}
\mathrm{CSA}_{\text {Total }} & =2.1675 \cdot \mathrm{DOB}^{1.9005}\left(p<0.001, r^{2}=0.87\right) \\
\mathrm{CSA}_{\text {Sapwood }} & =10.5500 \cdot \mathrm{DOB}^{1.3334}\left(p<0.001, r^{2}=0.86\right) .
\end{aligned}
$$

\section{DISCUSSION}

\subsection{Significance of heartwood in roots}

The presence of heartwood in roots is an important consideration in evaluating allometric relationships between roots, the rest of the vascular system, and foliage. Heartwood was present in the majority of sampled roots and it accounted for an average of $19 \%$ of total root CSA in the sampled trees. Sapwood was a decreasing proportion (and, conversely, heartwood was an increasing proportion) of total root CSA as the size of the root system increased. The effect of heartwood on allometric relationships depends, in part, on tree size and the particular relationship that is addressed. In small trees where heartwood is a small or negligible proportion of total CSA, it may not be necessary to separate sapwood from total root CSA (Carlson and Harrington, 1987; Kuiper and Coutts, 1992). Equations may also be developed for some purposes to simply predict root CSA or mass without distinguishing between sapwood and heartwood (Drexhage and Gruber, 1999; Thies and Cunningham, 1996). However, sapwood CSA should be measured or estimated when functional relationships involving root CSA 


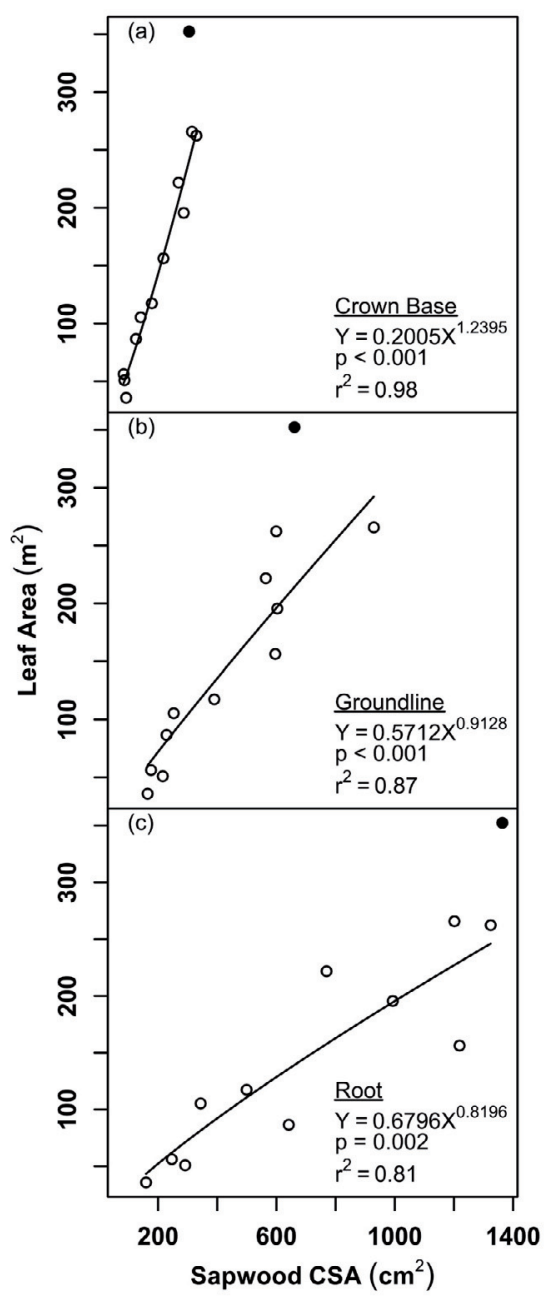

Figure 3. Relationship between leaf area (y-axes) and sapwood cross sectional area (CSA) (x-axis) when sapwood was measured at crown base (a), groundline (b) and in roots (c). Results are shown for nonlinear least squares regression fits to the allometric equation. Tree 5-A (filled point) had consistently high leaf area per unit of sapwood CSA and was not used to fit the equations.

are examined in trees large enough to contain significant heartwood. The conclusions reached may be quite different depending on whether total root CSA or sapwood CSA is measured. For example, the relationship between total root CSA and total CSA at groundline was close to the 1:1 line in the present study, while root sapwood CSA was clearly greater than sapwood CSA at groundline. The former analysis may be of interest for prediction or for comparing total root and stem growth, while the latter analysis better addresses the functional relationship between root and stem xylem.

\subsection{Extension of sapwood : leaf area relationships to roots}

The CSA of sapwood in roots was greater than that measured at any of the locations on the stem. Accordingly,

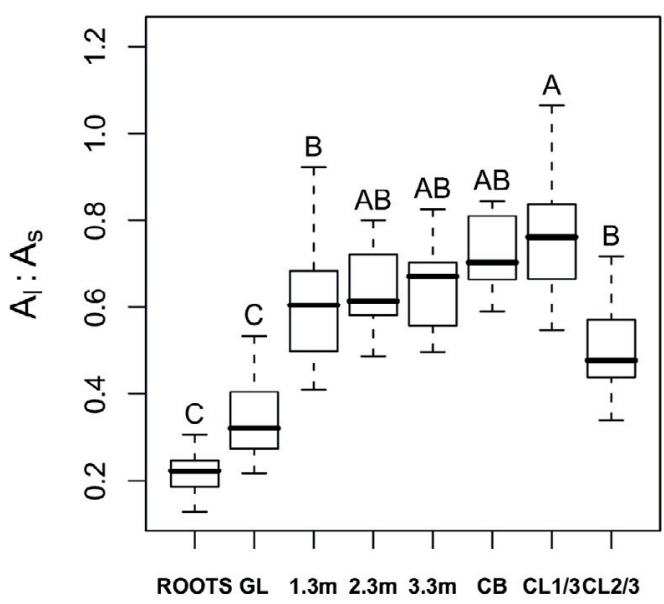

CSA Measurement Location

Figure 4. Box plot of leaf area : sapwood area ratios $\left(\mathrm{A}_{l}: \mathrm{As}\right)$ based on sapwood cross-sectional area (CSA) measured at different locations in the sampled trees. Tree locations represent sapwood in roots (ROOTS), groundline (GL), at $1.3,2.3$, and $3.3 \mathrm{~m}$, at crown base (CB), and at one-third and two-thirds of the crown length (CL1/3 and CL2/3). $A_{l}$ :As differed significantly between sections that do not share the same letter (experiment-wide $\alpha=0.05$ ). Symbols show the median value (heavy horizontal line), interquartile range (box length), and range of data within 1.5 times the interquartile range (dashed lines).

$\mathrm{A}_{l}: \mathrm{A}_{s}$ was lowest when sapwood was measured in roots. The CSA of sapwood at groundline was intermediate between that of the stem and roots. Parallel with the increase in sapwood CSA from crown base to roots was an increase in unexplained variation in the sapwood : leaf area relationship, suggesting that factors unrelated to the physiological support of foliage play an increasingly important role in determining total sapwood CSA below crown base and within roots. These results indicate that the pattern of sapwood taper that has been reported in the stem of Douglas-fir and other species (Gartner, 2002; Maguire and Hann, 1987; Waring et al., 1982), can be extended to roots. Stem taper is often viewed as a means to more uniformly distribute stress along a stem when force is applied to a tree crown due to wind, snow, or other factors (Dean et al., 2002). The trees in the present study were young (total age $=22-5 \mathrm{y})$ and fast growing and most of the CSA of the stem and roots was sapwood. Consequently, the quantity and distribution of sapwood largely determined overall stem taper. Stem sway caused by wind is a primary stimulus for the redistribution of xylem (thigmomorphogenesis) in trees (Telewski, 2006). The negative relationship between $\operatorname{root} \mathrm{A}_{l}: \mathrm{A}_{s}$ and relative tree height suggests that stem sway may have stimulated the radial growth of roots, resulting in greater sapwood CSA than might otherwise be required to physiologically support the tree crown. In young, fast growing trees such as those sampled in our study, the conversion of sapwood to heartwood may lag behind total sapwood production. However, the negative relationship observed in this study between the rate of CSA 


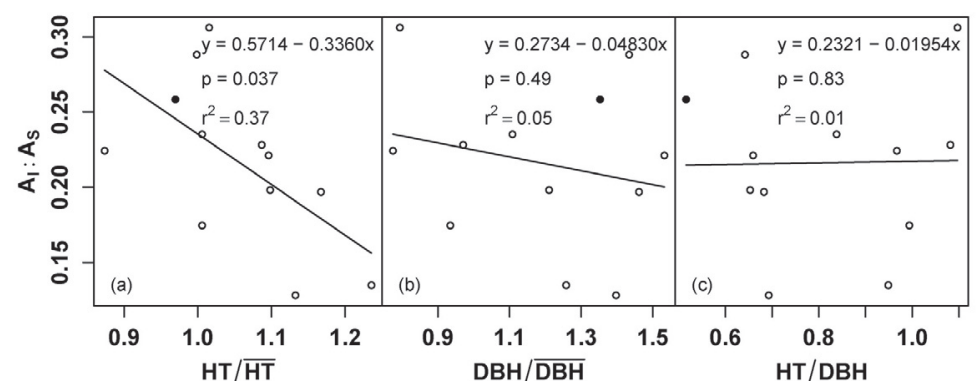

Figure 5. Relationships between leaf area / root sapwood cross-sectional area $\left(\mathrm{A}_{l}: \mathrm{A}_{s}\right)$ and variables related to the risk of toppling. Variables tested were (a) relative height (tree height / mean stand height), (b) relative diameter (tree diameter / mean stand diameter) and (c) tree height / tree diameter $(\mathrm{m} / \mathrm{cm})$. Ordinary-least squares regression results are shown for each relationship. Tree 5-A (filled point) had the greatest leaf area among the sampled trees, but its $\mathrm{A}_{l}: \mathrm{A}_{s}$ was consistent with the rest of the sample.
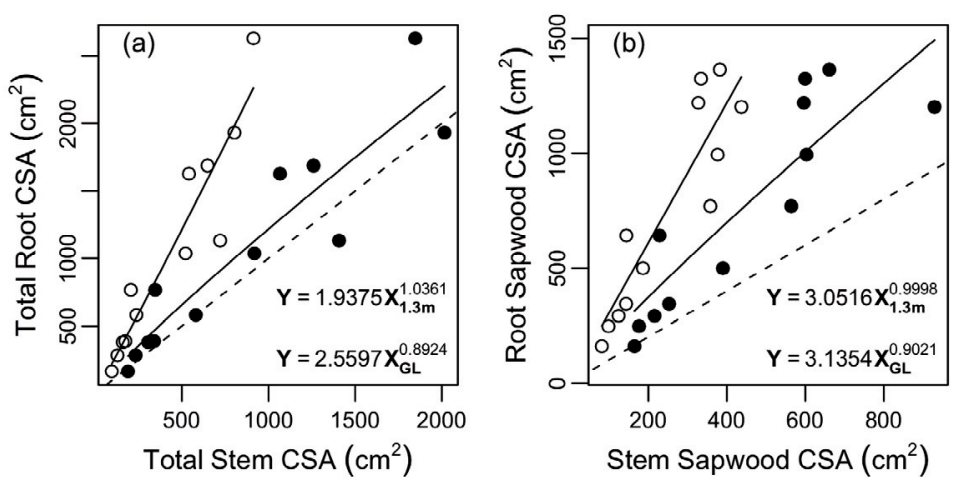

Figure 6. Relationships between root and stem cross sectional area (CSA). Dotted lines represent a 1:1 relationship between variables. Total root CSA is plotted against total stem CSA (a) and root sapwood CSA is plotted against stem sapwood CSA (b). Filled symbols represent stem CSA at groundline and open symbols show stem CSA at $1.3 \mathrm{~m}$ above the groundline. Equations show the results of non-linear least-squares regression fits for the allometric equation.

growth in individual roots and the number of rings in root sapwood provides some evidence that sapwood is converted to heartwood somewhat more rapidly in faster growing roots than in slower growing roots.

Other properties and functions of root sapwood beyond what would be expected under a simple pipe model may influence the quantity of root sapwood and root $\mathrm{A}_{l}: \mathrm{A}_{s}$. Darcy's law describes the volume flow rate of water as a function of sapwood conductivity, path length, pressure gradient, water viscosity, and sapwood CSA. Volume flow rate is inversely proportional to path length, thus an increase in sapwood CSA in the lower stem and roots may compensate for the increase in path length as trees grow taller (Tyree and Ewers, 1991). Sapwood conductivity also varies according to its position within the stem. Conductivity has been reported to increase with increasing height within the stem in Douglas-fir (Spicer and Gartner, 2001) and other tree species (Medhurst and Beadle, 2002; Spicer and Gartner, 2001; Whitehead et al., 1984). Water volume flow rate is directly proportional to sapwood conductivity and changes in this property may also partially explain the decrease in sapwood area from groundline to crown base (Whitehead et al., 1984). The conductivity of root sapwood is typically greater than that of stems in Douglas-fir seedlings
(Dunham et al., 2007; Kavanagh et al., 1999) and in small, nonstructural roots (Dunham et al., 2007). There is little information on sapwood conductivity within, or close to, the zone of rapid taper in Douglas-fir roots; however, an inverse relationship between root sapwood CSA and conductivity would be expected under the pipe-model theory.

\section{CONCLUSIONS}

The strong allometric relationship between leaf area and sapwood CSA measured in the stem can generally be extended to Douglas-fir root systems. However, the relationship becomes more variable when sapwood is measured below the base of the live crown. The previously reported pattern of increasing sapwood CSA from the base of the live crown to the base of the stem was found to extend to the roots, where total CSA was higher, and the proportion of heartwood was lower, than in the stem. The mechanical requirements of supporting and anchoring the tree, and possibly other factors, play important roles in determining the distribution of xylem within the stem and roots. Carefully designed experiments may be the only way to fully separate the mechanical and physiological functions of wood in the stem and roots. 
Acknowledgements: We thank the Washington Department of Natural Resources for access to study sites and permission to fell sample trees, our coworkers for help in harvesting and transporting roots systems and processing foliage samples, David Marshall for field assistance and suggestions on sampling and data analysis, and George McFadden, US Department of Interior, Bureau of Land Management, for financial support of data analysis.

\section{REFERENCES}

Berthier S., Kokutse A.D., Stokes A., and Fourcaud T., 2001. Irregular heartwood formation in Maritime pine (Pinus pinaster Ait): consequences for biomechanical and hydraulic tree functioning. Ann. Bot. 87: $19-25$.

Brix H. and Mitchell A.K., 1983. Thinning and nitrogen fertilization effects on sapwood development and relationships of foliage quantity to sapwood area and basal area in Douglas-fir. Can. J. For. Res. 13: 384-389.

Carlson W.C. and Harrington C.A., 1987. Cross-sectional area relationships in root systems of loblolly and shortleaf pine. Can. J. For. Res. 17: $556-558$

Dean T.I., Roberts S.D., Gilmore D.W., Maguire D.A., Lang J.N., O’Hara K.L., and Deymour R.S., 2002. An evaluation of the uniform stress hypothesis based on stem geometry in selected North American conifers. Trees Struct. Funct. 16: 559-568.

Drexhage M. and Gruber F., 1999. Above- and below-stump relationships for Picea abies: estimating root system biomass from breast-height diameters. Scand. J. For. Res. 14: 328-333.

Dunham S., Lachenbruch B., and Ganio L., 2007. Bayesian analysis of Douglas-fir hydraulic architecture at multiple scales. Trees Struct. Funct. 21: 65-78.

Gartner B.L., 2002. Sapwood and inner bark quantities in relation to leaf area and wood density in Douglas-fir. IAWA J. 23: 267-285.

Harrington C.A., and DeBell D.S., 1996. Above- and below-ground characteristics associated with wind toppling in a young Populus plantation. Trees 11: 109-118.

Hillis W.E., 1987. Heartwood and Tree Exudates. Springer-Verlag, Berlin, New York.

Kavanagh K.L., Bond B.J., Aitken S.N., Gartner B.C., and Knouve S.A., 1999. Shoot and root vulnerability to xylem cavitation in four populations of Douglas-fir seedlings. Tree Physiol. 19: 31-37.

Kuiper L.C., and Coutts M. P., 1992. Spatial disposition and extension of the structural root system of Douglas-fir. For. Ecol. Manage. 47: $111-125$.

Kutscha N.P., and Sachs I. B., 1962. Color tests for differentiating heartwood and sapwood in certain softwood tree species. Report 2246 US Department of Agriculture Forest Service Forest, Forest Products Laboratory, Madison WI $16 \mathrm{p}$.

Langstrom B., and Hellqvist C., 1991. Effects of different pruning regimes on growth and sapwood area of Scots pine. For. Ecol. Manage. 44: 239-254.

Maguire D.A., and Hann D.W., 1987. Equations for predicting sapwood area at crown base in southwest Oregon Douglas-fir. Cana. J. For. Res. 17: 236-241.

Margolis H.A., Gagnon R.R., Pothier D., and Pineau M., 1988. The adjustment of growth, sapwood area, heartwood area, and sapwood saturated permeability of balsam fir after different intensities of pruning. Cana. J. For. Res. 18: 723-727.

Margolis H.A., Oren R., Whitehead D., and Kaufmann M. 1995. Leaf area dynamics of conifer forests. in W.K. Smith and T.M. Hinkley, Eds. Ecophysiology of Coniferous Forests. Academic Press, San Diego, CA.

McArdle B.H., 2003. Lines, models, and errors: regression in the field. Limnol. d Oceanogr. 48: 1363-1366.
McDowell N., Barnard H., Bond B.J., Hincklry T., Hubbard R., Islui H., 2002. The relationship between tree height and leaf area:sapwood area ratio. Oecologia 132: 12-20.

Medhurst J.L. and Beadle C.L., 2002. Sapwood hydraulic conductivity and leaf area - sapwood area relationships following thinning of a Eucalyptus nitens plantation. Plant, Cell Environ. 25: 1011-1019.

Mencuccini M. and Grace J., 1995. Climate influences the leaf area/sapwood area ratio in Scots pine. Tree Physiol.y 15: 1-10.

Monserud R.A. and Marshall J.D., 1999. Allometric crown relations in three northern Idaho conifer species. Cana. J. For. Res. 29: 521-535.

Neter J., Kutner M.H., Nachsheim C.J., and Wasserman W., 1996. Appl. Linear Statistical Models, 4 ed. WCB McGraw Hill.

Niklas K.J., 1994. Plant Allometry: The Scaling of Form and Process. University of Chicago Press, Chicago.

Pinheiro J. and Bates D., 2000. Mixed-Effects Models in S and S-Plus. Springer, New York.

Pinheiro J., Bates D., DebRoy S., and Sarkar D., 2006. nlme: Linear and nonlinear mixed effects models. $\mathrm{R}$ package version 3.1-73.

R Development Core Team, 2006. R: A language and environment for statistical computing. R Foundation for Statistical Computing, Vienna, Austria. URL http://www.R-project.org.

Richardson A.D. and zu Dohna H., 2003. Predicting root biomass from branching patterns of Douglas-fir root systems. Oikos 100: 9-104.

Schabenberger O. and Pierce F. J., 2002. Contemporary statistical models for the plant and soil sciences. CRC Press.

Shinozaki K., Yoda K., Hozumi K., and Kira T., 1964a. A quantitative analysis of plant form: the pipe model theory I. basic analysis. Jpn J. Ecol. 14: 97-105.

Shinozaki K., Yoda K., Hozumi K., and Kira T., 1964b. A quantitative analysis of plant form: the pipe model theory II. further evidence of the theory and its application in forest ecology. Jpn J. Ecol. 14: 133139.

Spicer R., 2005. Senescense in secondary xylem: heartwood formation as an active developmental process. in N. M. Holbrook and M. A. Zwienicki, editors. Vascular Transport in Plants. Elsevier Academic Press, San Diego, PP. 457-475.

Spicer R. and Gartner B.L., 2001. The effects of cambial age and position within the stem on specific conductivity in Douglas-fir (Pseudotsuga menziesii) sapwood. Trees Struct. Funct. 15: 222-229.

Spicer R. and Holbrook N.M., 2007. Effects of carbon dioxide and oxygen on sapwood respiration in five temperate tree species. J. Exp. Bot.58: 1313-1320.

Telewski F. W., 2006. A unified hypothesis of mechanoperception in plants. Am. J. Bot. 93: 1466-1476.

Thies W.G. and Cunningham P.G., 1996. Estimating large-root biomass from stump and breast-height diameters for Douglas-fir in western Oregon. Cana. J. Forest Res. 26: 237-243.

Tyree M.T. and Ewers F.W., 1991. Tansley Review No. 34: The hydraulic architecture of trees and other woody plants. New Phytol. 119: 345360.

United States Department of Agriculture Natural Resources Conservation Service, 2006. Soil Survey Geographic Database for Pierce and Thurston Counties, WA. http://soildatamart.nrcs.usda.gov. (February $22,2006)$.

Waring R.H., Schroeder P.E., and Oren R., 1982. Application of the pipe model theory to predict canopy leaf area. Cana. J. For. Res. 12: 556-560.

Whitehead D., Edwards W.R.N., and Jarvis P. G., 1984. Conducting sapwood area, foliage area, and permeability in mature trees of Picea sitchensis and Pinus contorta. Cana. J. For. Res. 14: 940-947.

Wright I.J., Falster D.S., Pickup M., and Westoby M., 2006. Crossspecies patterns in the coordination between leaf and stem traits, and their implications for plant hydraulics. Physiol. Plant. 127: 445-456. 